Short communication

\title{
Rice brown spot Bipolaris oryzae (Breda de Haan) Shoemaker in Paraguay
}

\author{
Lidia Quintana $^{1}$, Susana Gutiérez ${ }^{2}$, Manuela Arriola ${ }^{1}$, \\ Karina Morinigo ${ }^{1}$ and Aldo Ortiz ${ }^{1}$
}

\author{
${ }^{1}$ Facultad de Ciencias Agropecuariasy Forestales-Universidad Nacional de Itapúa Encarnación, Paraguay \\ ${ }^{2}$ Universidad Nacional del Nordeste-Corrientes, Argentina
}

*Corresponding Author: lviedmaq@gmail.com

[Accepted: 20 November 2017]

[Cite as: Quintana L, Gutiérez S, Arriola M, Morinigo K \& Ortiz A (2017) Rice brown spot Bipolaris oryzae (Breda de Haan) Shoemaker in Paraguay. Tropical Plant Research 4(3): 419-420]

Brown leaf spot is a serious disease in rice production worldwide, caused by Bipolaris oryzae (Breda de Haan) Shoemaker, it is caused losses in stand due to seedling blight, in yield due to leaf and culm infection, and in quality and yield by kernel infection. In the 2014/2015 season, disease survey was conducted in the different rice-growing area of the country. Symptoms were observed on rice plants of IRGA 424 cultivar as leaf spot throughout the growing season, mostly on leaf blade and leaf sheath. Small spots were dark brown to reddish brown, circular to oval in shape, while older spots have a light, reddish-brown or gray center surrounded by a dark to reddish-brown margin.

In the national bibliography no history published about this disease was found, thus the objective of this study was to determine the etiology in this new disease in Paraguay. Naturally, diseased leaves of IRGA 424 cultivar infected in varied degrees with brown spot were collected from various districts of the country. Two hundred leaf samples taken from each field with symptoms and signs of brown spot.

Affected tissues from the leaves were cut into small bits, washed thoroughly in running water to remove dirts. These were dipped in $0.5 \%$ sodium hypochlorite $(\mathrm{NaOCl})$ solution for $30-45$ seconds and plated on 3 layers of moistened blotters in plastic petri dishes (ISTA 2003). The dishes were incubated at $25-30^{\circ} \mathrm{C}, 12 / 12$ hours light and darkness and examined under a stereomicroscope for the growth of B. oryzae after 7-10 days of incubation. Subsequently, the fungus spores were isolated on PDA for the colonies observation.
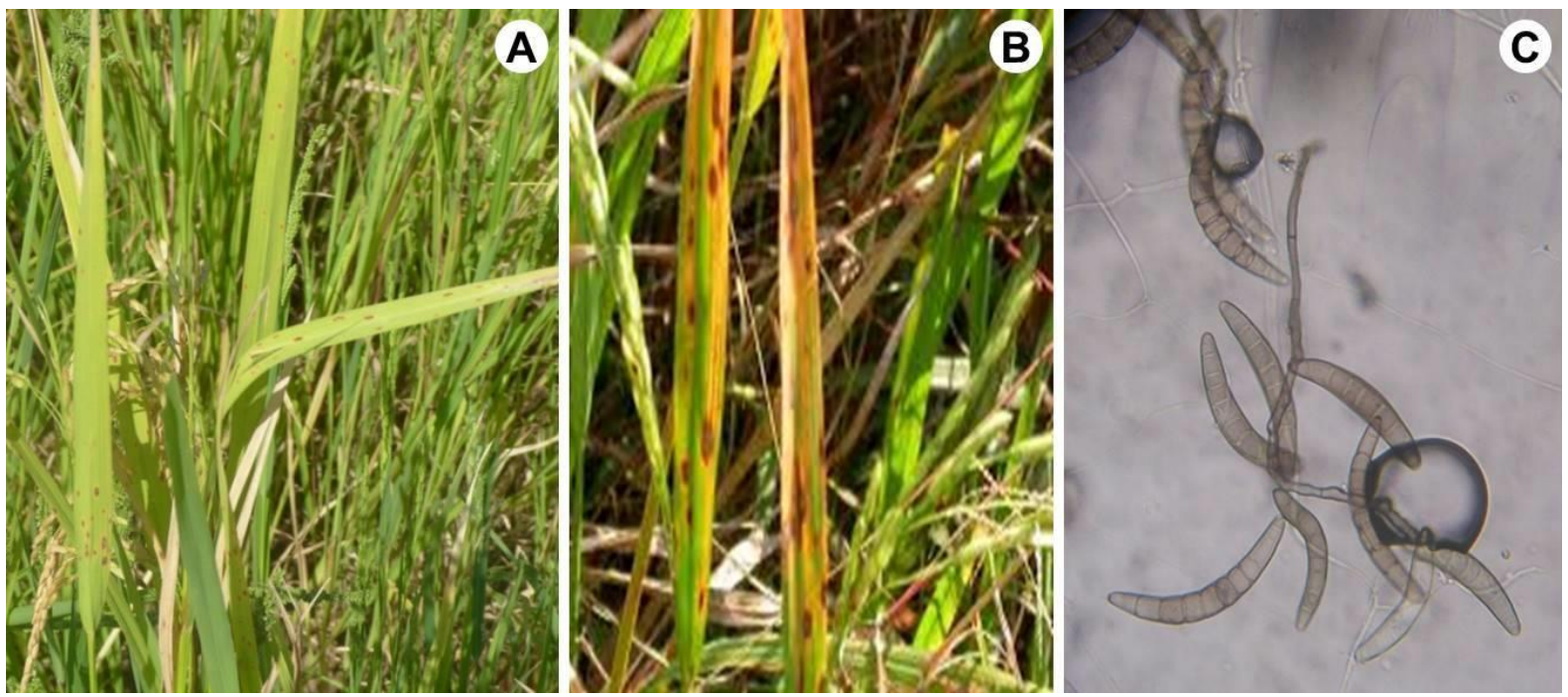

Figure 1. A-B, Symptoms of brown spot on rice leaves; C, Conidia of Bipolaris oryzae (Breda de Haan) Shoemaker.

The brown spot was detected in green rice plants at reproductive stage in IRGA 424 cultivar grown in the departments of Itapúa, Misiones and Caazapá. The mean disease incidence in leaves was 30-40\%. The disease 
has been described in all rice-producing countries in the world such, India, Pakistan, Bangladesh, Egypt, USA, Philippines, Colombia, Brasil and Perú (Ou 1985, Webster \& Gunnel 1992, Mew \& Gonzales 2002). In Egypt, the disease comes in the second rank after blast disease (El-Wahsh 1997). Gutiérrez et al. (2000) and Farias et al. (2011) reported the identification of Bipolaris oryzae and Bipolaris spp. in seed lots of Northern of Argentina and Rio Grande do Sul State, Brasil respectively.

The symptoms observed in this survey were similar with those described by Ou (1985), Webster \& Gunnel (1992), Mew \& Gonzales (2002). Symptoms are visible as small and circular dark brown spot, sometimes purple brown spots to ovalbrown spots with gray centers distributed on all leaf surface (Fig. 1A, B). Mycelia is gray to dark greenish gray and conidiophore septate, solitary, or in smallgroups; straight or flexuous, simple; pale to mid-brown; bearing conidia at the end and on sides. Microscopically conidia of Bipolaris oryzae club shaped to cylindrical, generally curved, light brown to golden brown, with 6 to 13 transverse cell walls (Fig. 1C) and were similar to those described by several authors (Ou 1985, Mew \& Gonzales 2002).

The causal agent of rice brown spot was identified as Bipolaris oryzae (Breda de Haan) Shoemaker. This is the first report of the disease in Paraguay.

\section{ACKNOWLEDGEMENT}

The authors are thankful to PROCIENCIA/CONACYT for their financial support.

\section{REFERENCES}

El-Wahsh SM (1997) Studies on both brown spot and blast diseases of rice in Egypt, Ph.D. Thesis. Tanta University, Egypt.

Farias CRJ, Afonso AP, Pierbom CR \& Ponte EMD (2011) Regional survey and identification of Bipolaris spp associated with rice seeds in Rio Grande do Sul State, Brazil. Ciencia Rural 41: 369-372.

Gutiérrez SA, Mazzanti de Castañón MA, Cúndom MA (2002) Hongos presentes en semillas de arroz del noreste de Argentina. Fitopatología 37:156-163.

ISTA (2003) Draper SR (ed) International rules for seed testing, rules. Zurich, Switzerland, ISTA.

Mew TW \& Gonzales PA (2002) Handbook of rice seed-borne fungi. International Rice Research Institute (IRRI) Los Baños, Philippines and Enfield, N.H., Science Publishers, Inc., USA, 83 p.

Ou SH (1972) Rice Diseases. CAB International Mycological Institute, KEW, Surrey, England, 368 p.

Webster RK \& Gunnel PS (1992) Rice Diseases. APS Press, Science, 62 p. 